\title{
The Effect of Earthquake Disaster Evacuation Simulation on Preparedness of The Imam Syafii Islamic Boarding School Community in Aceh Besar
}

\author{
Baihaqi ${ }^{1}$, Sulastri ${ }^{2}$, Taqwaddin Husin ${ }^{3}$ \\ ${ }^{I}$ Graduate Program In Disaster Science, Syiah Kuala University, Banda Aceh, 23111, Indonesia \\ ${ }^{2}$ Faculty of Teacher Training and Education, Syiah Kuala University, Banda Aceh, Indonesia \\ ${ }^{3}$ Faculty of Law, Syiah Kuala University, Banda Aceh, Indonesia
}

\{baihaqi@gmail.com\}

\begin{abstract}
School as one of the most effective media of science transformation which is expected to be able to absorb and apply knowledge on preparedness to face disasters by using the right and correct methods. In addition, schools also need to make disaster prevention as an important activity. Imam Syafii Islamic Boarding School Suka Makmur District is an Islamic boarding school with an area of $\pm 3 \mathrm{ha}$, there are various facilities for study rooms, prayer rooms, students dormitories, teacher dormitories, public toilets, libraries, and a number of sports facilities. This sturdy building made of concrete shows the vulnerability for students and teachers found in Islamic boarding schools because of their daily lives there. Moreover, the three levels students dormitory shows that they are very vulnerable to the earthquake disaster so that the preparedness of the students needs to be trained and more specifically the intensity of the earthquake that we cannot predict. This study uses experimental research methods. The population in this study were all students who studied in the Imam Syafii Sibreh boarding school, which consisted of 216 students. The sampling technique in this study was conducted by random sampling. The instruments used in this study were tests and non-tests. The test instruments were in the form of pretest and posttest questions, non-tests in the form of questionnaire sheets, and recording devices in carrying out earthquake disaster evacuation simulation studies. The results of this research can be concluded that the application of simulation methods is effective in increasing the preparedness of the school community in the face of earthquake disasters. The influence is based on the results of preparedness posttest which includes aspects of knowledge, attitudes, and preparedness actions, where each of these aspects increased by $79.6 \%, 75.87 \%$, and $85.0 \%$.
\end{abstract}

Keywords: School, Simulation, Preparedness.

\section{Introduction}

By mitigating and increasing community preparedness, it is hoped that humans can reduce the risk of disasters. Given the extraordinary impact, natural disaster management must be carried out using the right principles and methods. In addition, natural disaster management must also be comprehensive not only in the event of a disaster but prevention before a disaster and rehabilitation and reconstruction occur after a disaster occurs. 
One of the factors causing many fatalities due to disasters such as earthquakes is due to the lack of knowledge of the community including formal and non-formal educational institutions about disasters and their readiness to anticipate the disaster. Especially for earthquakes, many of the victims who died were caused by rubble due to collapsed buildings and the majority of fatalities were children and old age. This is because the elderly are the age most vulnerable to the risk of becoming a victim in a disaster [1].

Efforts to increase disaster preparedness must continue to be carried out to see that there are still many casualties and damage caused by earthquakes, such as earthquakes that occurred in Central Aceh, Bener Meriah and Pidie Jaya in August 2016. In addition to the Government, the community is also responsible and must be involved in efforts to reduce disaster risk, especially those in the disaster-prone areas, so as to increase the resilience of a nation in the face of disasters.

School as one of the most effective media of transformation of science which is expected to be able to absorb and apply knowledge on preparedness to face disasters by using the right and correct methods. In addition, schools also need to make disaster prevention as an important activity. This is an important first step in building disaster resilience throughout the community $[2]$.

After the earthquake and tsunami in Aceh, many institutions have been involved in providing training both through schools and communities to increase awareness and preparedness in the face of disasters. The students need to be guided not only to know and understand disasters but more important is how they can deal with disasters with an alert and responsive attitude so as to minimize disaster risk.

The young at the Middle School level is one part of the community that can be prepared, nurtured and trained to become human resources ready to face disasters. In order to build a culture of safety and resilience especially for the younger generation, one of them needs to be carried out further disaster preparedness training starting from elementary, secondary and so on. Learning from the experience of natural disasters and various disasters that occur in Indonesia, the training is very much needed which is related to the right way to save yourself when a disaster occurs and also how to prevent unnecessary accidents in everyday life.

In Aceh, especially Aceh Besar, there are 133 Educational Institutions in Salafiyah Islamic boarding schools with a total number of students reaching 14,054 people and teachers reaching 3,627 people [3]. One of them is Imam Syafii Islamic Boarding School, which is a religionbased educational institution that combines religion and general science. The schedule combines the school curriculum and the boarding school curriculum so that it makes the Islamic Boarding School have two levels of formal schools, the junior secondary and MA levels.

Imam Syafii Islamic Boarding School Suka Makmur District has an area of \pm 3 ha, there are various facilities for study rooms, prayer rooms, santri dormitories, teacher dormitories, public toilets, libraries, and a number of sports facilities. This sturdy building concretely shows the vulnerability for students and teachers found in Islamic boarding schools because of their daily lives in boarding schools. Moreover, the three levels of students dormitory shows that they are very vulnerable to the earthquake, so the preparedness of the students needs to be trained and increased especially the earthquake intensity that we cannot predict such as the twin earthquakes that occurred on February 16, 2017, at 02.47 WIB with a scale of 5.6 SR and continued at 02.53 WIB on a scale of $5 \mathrm{SR}$. 


\section{Methods}

This study uses experimental research methods. The population in this study were all students who studied in the Imam Syafii Sibreh boarding school, which consisted of 216 students. The sampling technique in this study was conducted by random sampling. Sampling in this study was carried out with a minimum sample formulation using the Slovin [4]. The instruments used in this study were tests and non-tests. The test instruments were in the form of pretest and posttest questions, non-tests in the form of questionnaire sheets, and recording devices in carrying out earthquake disaster evacuation simulation research in improving students preparedness in facing earthquakes in Imam Syafii Sibreh Islamic Boarding School, Aceh Besar.

The knowledgeability test in this study consisted of 10 multiple choice questions given at the beginning and end of the study. To get the criteria for good test questions, the question must be assessed for reliability, validity, level of difficulty and differentiation. Validity testing and construction validity aim to determine the suitability between the problem and the teaching material.

Every Pretest and Posttest is almost identical and has the same quality. The pre-test aims to find out the initial abilities of the students before getting treatment, while the Posttest aims to determine whether or not there is an increase in the students' knowledgeability after getting the learning treatment.

The data analysis technique used in this study is quantitative data analysis in the form of the test results of the knowledgeability of students preparedness and qualitative data in the form of attitudes and actions questionnaire on students preparedness in the face of earthquakes. Data processing is used SPSS and Microsoft Office Excel.

Test by using multiple choice has a value, that is answering questions correctly given a value of 1 (one), and for the wrong answer given 0 (zero) with the maximum value for each question is 140 .

Based on the results of the test questions, it can be seen the knowledge level category of the Imam Syafii Sibreh Islamic Boarding School community in Aceh Besar in the face of the earthquake in the following table

\begin{tabular}{cc}
\hline $\begin{array}{c}\text { Knowledge Percentage } \\
(\mathbf{\%})\end{array}$ & Category \\
\hline $0-20$ & Very Low \\
\hline $21-40$ & Low \\
\hline $41-60$ & Adequate \\
\hline $61-80$ & High \\
\hline $81-100$ & Very High \\
\hline &
\end{tabular}

Questions and statements to find out attitudes, preparedness actions and the effectiveness of implementing simulations are arranged in the form of questionnaires by answering odd tiered scales according to the Likert scale. In scoring on each question for aspects of attitudes and preparedness actions based on the number of respondents $\mathrm{x}$ each choice of answers $(1-5)$, then divided by the highest number of scores $(5 \times 30=150) \times 100 \%$.

While calculating the effectiveness of the implementation of the simulation also uses the same method, but based on the number of observers $x$ each answer choice (1-5), then divided by the highest number of scores $(5 \times 10) \times 100 \%$. 
Based on the results of the questionnaire, it can be seen the categories of attitudes, actions, and effectiveness of the implementation of earthquake disaster simulations in the following table

\begin{tabular}{ccccc}
\hline \multirow{2}{*}{ No } & Value (\%) & \multicolumn{2}{c}{ Variable } & Effectivity \\
\cline { 3 - 5 } & $80-100$ & Attitudes & Preparedness Action & Very Effective \\
\hline 1 & $65-79$ & Good & Very Ready & Effective \\
\hline 3 & $55-64$ & Adequate & Relatively Ready & Adequte \\
\hline 4 & $40-54$ & Bad & Less Ready & Ineffective \\
\hline 5 & $0-39$ & Very Bad & Not Ready & Very ineffective
\end{tabular}

The research was taken by conducting disaster simulations. Based on Priambodo[6] preparation was carried out by disseminating activities, coordinating related parties, installing disaster signs, making simulation scenarios, rehearsals, and implementing simulations.

\section{Result And Discussion}

School Community Knowledge About Earthquake Disasters and Preparedness. Based on the answers to the disaster and preparedness (pretest and posttest) knowledge questions, then recapitulated according to the test stages, the level of knowledge of the disaster and preparedness of the Imam Syafii Sibreh Islamic Boarding School, Aceh Besar, before and after the simulation based on the results of the pretest and posttest can be explained as follows:

\section{a. Analysis and Discussion of Pretest Results and Postest of Disaster and Preparedness Knowledge}

Based on the overall pretest questions, it can be said that the community's knowledge of earthquake disasters is classified as adequate, where all the questions answered correctly by the community are $60.3 \%$. It illustrates that in general the knowledge of the disaster and preparedness of the Imam Syafii Sibreh Islamic boarding school community is not satisfactory and requires efforts to increase knowledge of disaster and preparedness in the face of earthquake disasters. In general, the posttest results for aspects of earthquake disaster knowledge and preparedness were $79.6 \%$ or relatively high.

After the implementation of the simulation, the level of knowledge of earthquake disaster and preparedness, the knowledge of the school community has been very good. This is obtained from the average who answered correctly for each question increased from pretest $60.3 \%$ to $79.6 \%$ in the posttest. Therefore, it can be concluded that the knowledge of disaster in each community is very high so that it is expected to reduce the risks that occur when an earthquake strikes.

The analysis of these results illustrates the increase in knowledge of the Sibreh Imam Syafii Islamic Boarding School community which was obtained after a comparison of the results of the pretest and posttest. This increase in yield is also influenced by the effectiveness of the simulation itself, which means that after the treatment of the community, namely socialization and simulation, the community can absorb various information on disaster preparedness and preparedness. 


\begin{tabular}{lcccc}
\hline \multirow{2}{*}{ ques } & \multicolumn{3}{c}{ Pretest } & Posttest \\
\cline { 2 - 5 } & Incorrect & Correct & Incorrect & Correct \\
\hline Q1 & 19 & 121 & 8 & 132 \\
\hline Q2 & 49 & 91 & 17 & 123 \\
\hline Q3 & 76 & 64 & 41 & 99 \\
\hline Q4 & 48 & 92 & 23 & 117 \\
\hline Q5 & 63 & 77 & 28 & 112 \\
\hline Q6 & 77 & 63 & 23 & 117 \\
\hline Q7 & 45 & 95 & 25 & 115 \\
\hline Q8 & 46 & 94 & 19 & 121 \\
\hline Q9 & 84 & 56 & 44 & 96 \\
\hline Q10 & 28 & 112 & 17 & 123 \\
\hline
\end{tabular}

\section{b. Hypothesis Test of Differences in Disaster Knowledge and Community Preparedness}

Based on the results of the study, it was found that there was a significant difference in the knowledge of the Imam Syafii Sibreh Islamic Boarding School community in Aceh Besar after the implementation of the earthquake disaster simulation.

\section{c. Analysis and Discussion of Pretest and Posttest Attitudes Result of School Community Preparedness in Earthquake Disasters}

Based on the overall pretest questions, it can be said that the community's attitude about earthquake disasters is classified as sufficient, where all the questions answered correctly by the community are $62.4 \%$. This attitude value is still considered risky because $62 \%$ is a value that is not yet in the good or very good category for preparedness.

The posttest results for aspects of earthquake disaster preparedness were $75.87 \%$ or relatively good. After the implementation of the simulation, the level of preparedness in dealing with earthquake disasters in the school community has been very good. Therefore, it can be concluded that the preparedness attitude of each community is in a good category, so it is expected to reduce the risks that occur when an earthquake strikes.

After the implementation of the simulation, the assessment of the level of preparedness in dealing with earthquake disasters in the school community has been very good. This is obtained from the average who answered precisely for each question increased from pretest $62.4 \%$ to $75.87 \%$ at posttest. Therefore, it can be concluded that the preparedness attitude of each community is in a good category, so it is expected to reduce the risks that occur when an earthquake strikes.

From the comparison of the results of the pretest and posttest preparedness attitudes, the change in attitude will invite friends to find a safe place when aftershocks occur, which is the highest attitude change, which is $59.3 \%$.

The final results were achieved by the Imam Syafii Sibreh Islamic Boarding School community, Aceh Besar, in the aspect of preparedness attitude that was classified as high (75.87\%), this was expected to influence the attitude of each individual in the future school environment in facing earthquake preparedness.

A similar study conducted by Daud et.al.[7] and Finzia [8] in primary schools, found that after students and the school community were given treatment or learning after the pretest, it turned out that the attitudes of students and school communities were increasing towards more 
positive in the face of an earthquake. Research on attitudes in the face of disasters conducted by Lena Wida[9] concluded that knowledge, attitudes, and support of family members significantly influence household preparedness in the face of earthquake disasters. This can occur because the attitude variable is a major factor in preparedness in the face of disasters, especially earthquakes. Based on the results of previous studies it was found that the attitudes of school community preparedness can be improved if there are treatments applied to the school community, both in the form of training, learning, and simulation.

\section{d. Hypothesis Test of Differences in Attitudes of Community Preparedness}

Testing the hypothesis to see whether there is a significant difference in the preparedness attitude of the Imam Syafii Sibreh Islamic boarding school after the implementation of the earthquake simulation, the t-test was used, where the values of community preparedness attitudes obtained from the pretest and posttest were then compared.

The results obtained for testing preparedness attitudes proved that the probability value or $\mathrm{p}$-value is obtained $=0,000$, which means there are differences in preparedness attitudes before and after the implementation of the simulation because the $p$-value is $<0.05$. For the comparison of $t_{\text {count }}$ with $t_{\text {table }}$ value, the $t_{\text {count }}$ obtained is -23.557 and $t_{\text {table }}-1.977$, thus it is accepted H0, because of tcount $\leq t_{\text {table }}$ which means there are differences in community preparedness attitudes before and after the implementation of earthquake disaster simulation. The $t_{\text {count }}$ is compared

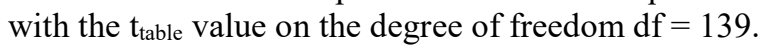

\section{e. School Community Preparedness Actions in the Face of Earthquake Disasters}

On the aspect of preparedness, action testing is carried out as aspects of knowledge and attitudes, namely testing the pretest and posttest using the same questionnaire. A total of 140 respondents answered questions on this aspect and there were no missing answers.

\section{f. Analysis and Discussion of Pretest and Posttest Result of School Community Preparedness Measures in Earthquake Disasters}

Based on the overall pretest questions, it can be said that the community's actions regarding earthquake disasters are classified as sufficient, where all the questions answered correctly by the community are $58.0 \%$. The value of this attitude is still relatively ready when viewed from his preparedness. This happened because before this research was conducted, there had never been an earthquake disaster simulation in Imam Syafii Sibreh Islamic Boarding School, while the learning of earthquake material was very limited. In general, the posttest results for aspects of earthquake disaster preparedness measures were $85.0 \%$ or classified as very good. Thus the percentage of aspects of school community preparedness attitudes at the pretest is (5952: 7000) $\mathrm{x} 100 \%=85.0 \%$, meaning that it is classified as very good $(80 \%-100 \%)$.

After the implementation of the simulation, the level of preparedness in dealing with earthquake disasters in the school community has been very good. This is obtained from the average who answered correctly for each question increased from pretest $58.0 \%$ to $85.0 \%$ in the posttest. Therefore, it can be concluded that the preparedness actions of each community are in a very good category, so it is expected that actions to reduce the risks that occur during an earthquake.

Based on the results examined in the preparedness aspect of the Imam Syafii Sibreh Islamic boarding school community can be described and becomes an important reason that these results 
are obtained when the community has gotten socialization of prior knowledge and attitude so that at the stage of taking practice/simulation, the community can be more understand so that you can practice preparedness correctly, not panic and be effective.

\section{g. Hypothesis Test of Differences in Community Preparedness Measures}

The results obtained for testing preparedness measures proved that the probability value or $p$-value is obtained $=0,000$, which means there are significant differences because the $p$-value

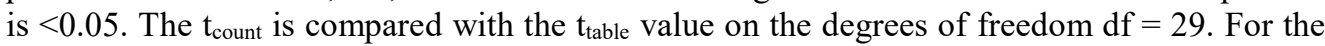
comparison of $t_{\text {count }}$ with $t_{\text {table }}$, then the tcount obtained is -48.605 and $t_{\text {tabel }}-1.977$, thus $\mathrm{H}_{0}$ accepts due to $t_{\text {count }} \leq$ table, which means that there are significant and significant differences in community preparedness actions before and after the simulation.

\section{Conclusion}

Based on the research that has been done at the Imam Syafii Sibreh Islamic Boarding School community in Aceh Besar, it can be concluded that the application of the simulation method is effective in increasing the preparedness of the school community in the face of earthquake disasters. The influence is based on the results of preparedness posttest which includes aspects of knowledge, attitudes, and preparedness actions, where each of these aspects increased by $79.6 \%, 75.87 \%$, and $85.0 \%$.

\section{REFERENCES}

[1] Iskandar, "Situasi kebencanaan aceh terkini," in Workshop Penggalangan Peer Group Peneliti Kebencanaan TDMRC, 2010.

[2] Khairuddin, Ngadimin, A. Sari, and T. Fauziah, Identifikasi pelatihan kebencanaan pasca tsunami dan dampaknya terhadap kesiapsiagaan komunitas sekolah dalam pengurangan risiko bencana di Provinsi Aceh. Banda Aceh: Universitas Syiah Kuala, 2010.

[3] Kementerian Agama Provinsi Aceh, "Jumlah lembaga pondok pesantren," 2017. .

[4] C. G. Sevilla, Research methods. Quezon: Rex Printing Company, 2007.

[5] S. Arikunto, Prosedur penelitian suatu pendekatan praktik. Jakarta: Rineka Cipta, 2010.

[6] A. Priambodo, Panduan praktis menghadapi bencana. Yogyakarta: Kanisius, 2009.

[7] R. Daud, S. A. Sari, S. Milfayetty, and M. Dirhamsyah, "Penerapan pelatihan siaga bencana dalam meningkatkan pengetahuan, sikap, dan tindakan komunitas SMA negeri 5 banda aceh," J. Ilmu Kebencanaan Pascasarj. Univ. Syiah Kuala, vol. 1, no. 1, pp. 26-34, 2014.

[8] P. Z. Finzia, "Pengaruh metode simulasi pengurangan risiko bencana terhadap kesiapsiagaan siswa sekolah dasar dalam menghadapi ancaman bencana gempa bumi di sd ulee paya pulo breuh aceh besar," Universitas Syiah Kuala, 2015.

[9] Lenawida, "Pengaruh pengetahuan, sikap dan dukungan keluarga terhadap kesiapsiagaan masyarakat menghadapi bencana gempa bumi dan tsunami di desa mon raya kecamatan syiah kuala banda aceh. Tesis tidak dipublikasikan," Universitas Sumatera Utara, 2011. 